\title{
China Controls Business Actors to Implement Belt and Road Initiative as Connectivity Project
}

\author{
${ }^{1}$ Aspin Nur Arifin Rivai \& ${ }^{2}$ Asra Virgianita \\ 1askaspin@gmail.com,2asrahiui@ui.ac.id \\ ${ }^{1}$ Postgraduate Progran Department of International Relations, Faculty of Social and Political \\ Sciences, Univerisitas Indonesia, Indonesia \\ ${ }^{2}$ School of Strategic \& Global Studies and Faculty of Social \& Political Sciences, Universitas \\ Indonesia, Indonesia
}

\begin{abstract}
This paper examines the relationship between state and business in China's foreign economic policy called BRI. Departing from the theory of state penetration on business actors, this study confirms that the connectivity agenda through BRI contains China's economic and political motives in Southeast Asia. The strategic objective is to deepen internationalization and cooperation relationships. This research shows that business actors play an important role in promoting China's strategic interests through BRI. The industry of railway infrastructure and transportation construction is part of China's control. The penetration process takes place in four determinant factors. First, BRI's policy is used as a national development program in order to unify the relationship between central and subnational government. Second, the objectives between government and business actors are compatible. Finally, the relationship between the government, the two industrial sectors and the involvement of business actors becomes directive and hierarchical - because the government controls the ownership system, the company management system, and the company's leadership structure. The results of this study indicate that the state has successfully controlled business actors.
\end{abstract}

Keywords: BRI, State-Business, Agenda of Connectivity, Internationalization and Railway Infrastructure and Transportation Industry.

\section{PRELIMINARY}

The development of China's foreign economic policy under the leadership of Xi Jinping has shown a new trait, i.e. the more complete position on globalization or connectivity agenda in accordance with the offers and ideas presented by China itself. This refers to the "Belt and Road Initiative" which was promoted at the end of 2013 when Xi Jinping made a state visit in Kazakhstan and Indonesia. 
This initiative is an ambitious policy carried out by China with the Silk Road model in mind that was part of its golden age in the past centuries. The mission to create economic connection between Asia, Europe and some other continent has become an important part in the current foreign policy of China. Currently, BRI has included more than 60 countries involved in the mega-connectivity program, in which China has traded for USD 3 trillion after the promotion of BRI. According to L Yong, deputy chairman of the China International Trade Association, China has made an investment of more than USD 50 billion along the BRIrelated connectivity program, while its companies have created 180,000 new jobs in the 20 countries involved in BRI cooperation program (Gjoza, 2017). In addition to contributing to state revenues, Chinese companies have become the new icon in promoting the country's strategic interests. To demonstrate this condition, this paper will explore the relations between state and business actors - where business interests and strategic political interests through BRI can be identified.

This article is organized into four parts. The first part presents debates about BRI's emergence as a form of China's economic and foreign policy. The second part outlines the convergence of interests between business actors, the government, and the government circle in viewing and positioning the presence of BRI programs as China's domestic and international policies. The third part outlines the form of state control on China's two industrial sectors. The last part elaborates the results of state control on business actors in BRI in Southeast Asia. The main finding of this study is that the Chinese government has succeeded in controlling business actors - i.e. the service provider for transportation and railway infrastructure - which serve important purpose in implementing BRI, specifically by bringing and continuing the strategic interests of Chinese Administration.

\section{BRI AND CHINA'S ECONOMIC STATECRAFT}

One of the most important events in the 21 st Century was the initiation of a new multilateral cooperation called BRI. This collaboration was first declared by Xi Jinping during a state visit in Kazakhstan on September 7, 2013. In his speech, Xi Jinping proposed a cooperation under the name of "Silk Road Economic Belt" which will link China and the European region through Central Asia, West Asia and Russia. Three weeks later, Xi Jinping announced the cooperation named the 21st Century Maritime Silk Road in Indonesia. This 'road' will connect China and the Mediterranean region through the maritime routes of Southeast Asia, the East Coast of Africa, and West Asia. The Silk Road-based cooperation will connect land and maritime regions that are connected to each other with membership amounts to more than 60 countries. In realizing BRI, the Chinese government is willing to channel infrastructure funds in the amount of USD124 billion. This fund was entrusted to BRI financial institution called Asia Infrastructure Investment Bank (AIIB) and the Silk Road Fund.

Several existing studies have revealed China's motive and objective through BRI. Based on the literature review, the authors find that there are two different perspectives on China's motive and objective in BRI, namely: strategic political rationality and economic rationality.

The first perspective argues that BRI is basically China's effort to improve its status in the regional and international political economy structure. This argument is made based on a variety of fundamental considerations, such as the agenda of securing energy supplies from the Indian Ocean and South China Sea, domestic security, and minimizing the risk of backlash from the US (Clarke, 2017; Len C, 2015; Ye, 2015; Wang, 2015; Aoyama , 2017; Ploberger, 
2017; Rolland, 2017). Long before the emergence of BRI, observers of contemporary realism experts had predicted that China's economic and foreign policy agenda would continue to strive to maintain its resurgence in order to balance the dominance of the US (Ikenberry, 2012; Mearsheimer, 2014). In fact, they argue that in order to balance the dominance of a hegemon, a state needs to be able and willing to provide alternative order - such as in the case of US during its hegemonic era.

The second perspective argues that the purpose of BRI is rather unique due to relying on economic rationality or domestic economy considerations. Amid the 2008 financial crisis that triggered global economic recession, China emerged as a country that was also affected by external economic challenges. It should be noted that China has excess investment (overinvested) and is hampered by domestic production problem (overcapacity). In line with these economic frictions, it appears that Beijing Administration viewed BRI as one of the main solutions in solving existing problems. Basically, BRI is China's pragmatic agenda to overcome its excesses and encourage many Chinese domestic companies, especially stateowned enterprises (SOEs), to be involved in infrastructure development projects along the BRI road (Junxian \& Yan, 2016; Tsui, et al., 2017; Rolland, 2017). In other words, BRI is an instrument to encourage the acceleration of domestic economic development based on several factors, e.g.: the development modalities of service, technology and infrastructure industries (Lin, 2015).

In regional arena, BRI's presence can stimulate economic cooperation in a much more complex region - followed by several strategies, namely (1) efforts to reduce development gaps and accelerate regional connectivity (Hong, 2016; Jetin, 2018); (2) turning the region into part of China's economic circle and encouraging expansion of Chinese companies in the regional infrastructure development sector (Yu H., 2017); (3) encouraging the rate of investment and assistance in infrastructure development (Callaghan \& Hubbard, 2016; O'Trakoun, 2017); and (4) developing Chinese industry cooperation with various strategic country partners (Jianren, 2016). Broadly speaking, the literature from this perspective shows that BRI's presence is a continuity of the Open Policy that was legalized by early Chinese reformers.

The above two perspectives can be interrelated under certain condition - i.e. if the state is able to control, discipline, and define the interests of business actors coherently with the interests of the state. In other words, state and business actor has a compatible interest by viewing the expansion of business as a way to maintain China's resurgence, while the expansion of Chinese diplomacy is viewed as a way to strengthen business activities overseas. However, this kind of analytical framework has not been found in existing studies. On that basis, this research proposes a new framework to explain BRI as China's foreign economic policy agenda by identifying the process of state penetration in influencing business actors for strategic economic and political agendas at the regional level through BRI. This research borrows the theory on state and business relations which is, as William J. Norris theorized, capable of creating an economic statecraft. In his work entitled " Chinese Economic Statecraft: Commercial Actors, Grand Strategy, and State Control " Norris (2016) has contributed significantly to the theorization of contemporary state economy. He argued that there are four determinant factors that can make a business actor have an interest in the government-related strategic agenda. Norris called it "state control."

First, unity or division within the bureaucracy or government. This factor aims to determine the extent to which this unit acts in harmony (unity of the state) for the sake of strategic economy. Norris offered several considerations that could influence the government 
environment at the domestic level, namely: (1) ideological perspective, (2) domestic politics, and (3) national special interests.

Second, compatibility or incompatibility of objectives between policy-makers and business actors. Under certain circumstances, the objective of business actors are often incompatible with the interest of the government, giving rise to a frictional relationship. Basically, business actors depend on their pragmatic interests, namely the value of profits, market expansion, security of access to basic inputs, increased productivity, and so on.

Third, the number of business actors in the market structure. There are three general classifications of market structure in a country, namely diffused/competitive, oligopoly and monopoly. Diffused is a market which includes various types of business actors or companies in the same field or sector. Oligopoly is a market structure that is dominated by only a few companies. This results in a state of limited competition. Companies can compete or collaborate with each other. Thus they can use collective market power to influence market structure and get more profits. Monopoly refers to the market structure in which a single company controls the entire market. In this scenario, the company has the highest level of market power, because the market arena no longer has an alternative. As a result, monopolies often reduce output to obtain much greater profits.

Finally, the nature of reporting relationship (reporting) between business and government actors. This relationship basically consists of three attributes, namely: (1) ownership of a company; (2) management arrangements, and (3) financing structure. If there is a direct relationship between these two actors, it will be easier for the government to control the business actor.

\section{STATE AND BUSINESS RELATIONS IN THE BRI PROGRAM}

The expansion of Chinese SOEs is one indication that shows "China's rise". The agenda to distribute Chinese companies at the international level has been pushed through a national policy called "China's Go Out" or the internationalization of company in 1999/2000 (Zweig, 2002). Along with the implementation of this policy, China gained its momentum to further expand its business activity network since the WTO's accession in 2001.

In 2010, more than 30,000 Chinese companies have operated overseas. Half of these companies are SOEs. This type of company has contributed more than $80 \%$ of China's outward investment (Zhang J., 2010). The most significant development in the distribution of the company took place after the 2008 Global Financial Crisis (GFC). GFC conditions naturally brought havoc to global trade and investment disability. Even so, this phenomenon was actually important for the expansion of Chinese companies. Hel Liu (2015) claims that GFC certainly has implications for disrupting productivity in the economies of capitalist countries. However, it also has resulted in an important change in the position of the state in an international economic configuration. Furthermore, Liu stressed that the global recession had an important meaning for China which he called as the "period of strategic opportunity" meaning the Beijing Administration has the momentum to develop its economy while increasing its position in the global international economic arena (Liu, 2015). Before the crisis occurred, China has already prominent in market expansion and capital flows. GFC then turned it into a strategic opportunity for China to increase its domestic market, expand infrastructure investment, and increase foreign technology acquisition. In a much simpler words, this opportunity has been very meaningful for the internationalization of Chinese companies. 
Among the 100 Chinese multinational companies, as published by the Confederation of Chinese Companies, there are 84 SOEs, of which 50 are national (central) SOEs with foreign assets amounting to RMB 4.5 trillion and 34 are sub-national (provincial) SOEs with foreign assets amounting to RMB 500 billion. In 2015, the Chinese government had foreign assets of RMB 12 trillion. According to statistical data released by the Ministry of Commerce of China, in 2014 - Chinese companies had channeled direct investment of USD 116 billion, making China a country with a large trade balance (Feng, 2016). This achievement was also noted by Fortune 500 where in 2015, 98 of the largest companies in the world were from China and three quarters of them were SOEs (Cendrowski, 2015). Compared to the year of 2010, there were only 10 companies on that list, but they are currently very close to toppling US in the first position.

Looking at the facts above, we can produce a fundamental question, i.e. whether the presence of Chinese business actors or companies that are increasingly expansive contributes effectively in maintaining the pace of China's economic resurgence, or at the same time being used as an important instrument in geo-political orientation and geo-economics? Broadly speaking, the authors have collected two forms of analysis that are opposite to each other in viewing and positioning the role of Chinese business actors in foreign markets in regard to the relationship between state and business actors.

The first perspective justifies that even though SOE is formed and controlled by the state, this entity is not fully within the control of the state. This is supported by the simple logic that business actors tend to be autonomous when in the external market arena which makes them a market-driven actor (Gonzalez-Vicente, 2012). Jun Zhang (2010) considered that the expansion of Chinese companies abroad could not be considered as the 'arms of state power', as their goal is to find new markets and supplies in accordance with pragmatic economic interests. As such, Chinese SOEs, even though were created by the state, will turn into profitseeking entities under certain circumstances (Zhang J., 2010). Then, Jie Yu (2012) argued that the actual expansion of Chinese companies could not be justified as being in full-control of the Beijing Administration (arms of state power). Despite the active participation of Chinese companies in global trade and investment, they still have very little global business exposure (Yu J., 2012, p.35). The criticism shown from this idea is that the close relationship between the Beijing Administration and SOEs in turn has limited the ability of the actor to become an influential player in international economic activities. In other words, state control of business actors has distracted the process of internationalization of Chinese companies, while reducing the presence of business actors into simply China's geo-economic agents.

On a contrary, another perspective views the expansion of Chinese companies is carried out under the condition of directive and hierarchical relations from the state to business actors, especially SOEs. This means that the state has strict control on business actors. Beijing's administrative orientation deepens its influence on business actors - turning them into vehicles for driving China's ambitions to become a superpower in international economic and political structures. In other words, the existence of Chinese business actors in the external market is used to fill and develop "China's Rise". Fred Robins (2013) in his article shows that Chinese SOEs have become agents or tentacles of Beijing's Administrative policy (Robins, 2013). Similarly, Erica S. Downs (2014) also confirmed that the expansion of Chinese companies was not merely a corporate internationalization. In fact, SOEs have been directed to prioritize and implement the geopolitical interests of Beijing Administration. As such, the existence of companies such as China's energy sector is to deliberate Western policies by collaborating with partner countries such as Myanmar to support China's expansion in the South China Sea (Downs, 2014). 
Of the two approaches above, the author argues that the first perspective of doubting state control can be used effectively when viewing business actors in external market arena, while the second perspective only sees state control as relevant only in the case of natural resources sector. Although different, these two assumptions do not have significant contradictions, because they both realize that business actors are economic entities that do not merely exist as profit-seeker but also capable to become political and economic seeker. To deepen this analysis, this paper simplifies it into one main question, namely how does the state controls business actors in sectors other than the natural resources sector? This question is relevant given that the presence of BRI can be observed via the connectivity agenda a la China. Precisely, this study was designed to explain the process of state penetration on business actors in fulfilling the objective of Chinese government to gain strategic, business and political benefits through BRI. In the theoretical framework employed in this research, measurement of state penetration can be made by looking at the actor variables, namely: the government and the state, and the government and the government.

\subsection{Objective Compatibility}

Chinese government's control on business actors has been increasingly prevalent since Xi Jinping's election as CCP Secretary General and President of China. At the beginning of his leadership, he made a policy to redesign the relationship between the state and business actors. This was focused on a deepening of economic reform to overcome the economic slowdown experienced by China after GFC 2008. Explicitly, XI Jinping described the intent of the policy in the Third Plenary Session of the 18th CCP Congress, on November 2013, namely: (1) economic reform is designed to play a decisive role in allocating national resources; and (2) emphasizing the government's need to encourage, support, and facilitate business entities, namely private companies and SOEs. Amid that event, the Central Committee of CCP reaffirmed that SOEs will become leading actor in the future national development plan (China.org.cn, 2014).

This condition has become a basis for the Chinese government to maintain their control on business actors. The presence of business actors has been interpreted as an important key to China's economic might. Next, economic achievement is also essential for the continuity of the legitimacy of CCP regime (Rolland, 2015). With that, the CCP regime seeks to maintain a monopolistic attitude in designing national policies when facing economic challenges, while at the same time trying to bring China to stand firm as a country with spectacular growth.

China's economic slowdown after GFC 2008 has become a special and inseparable part of the formation of BRI. This can be interpreted as economic rationality, all of which summarize China's policies in overcoming the decline of its Gross Domestic Product from 14.2\% in 2007 to $9.6 \%$ in 2008. Interestingly, amid its focus to manage domestic economy, the Chinese government realized that the problem of economic slowdown is not only caused by external factors, i.e. the global recession, but also internal factors. Dwight Perkins (2015) noted that the decline in China's GDP is caused more by structural economic problems in the domestic arena. This is clearly illustrated through his observations of two fundamental issues, namely: (1) the supply side shows that the total value of domestic productivity has slowed down; and (2) the demand side shows that household income tends to be low which requires the state to maintain higher investment in the infrastructure sector, because the share of manufacturing has reached the peak of industrial production since 2008 (Perkins, 2015). However, the Chinese 
government has realized that the economic slowdown is caused more by excess of production, especially in the heavy equipment industry (Peston, 2015).

In Harry X. Wu's research, China's TFP growth has steadily declined from $1.5 \%$ during $1992-2001$ to $1.2 \%$ during $2002-2007$ and then to $0.2 \%$ in $2008-2010$ (Wu, 2014). The data below shows that China's growth model several decades ago could no longer rely on exports of labor-intensive and heavy goods.

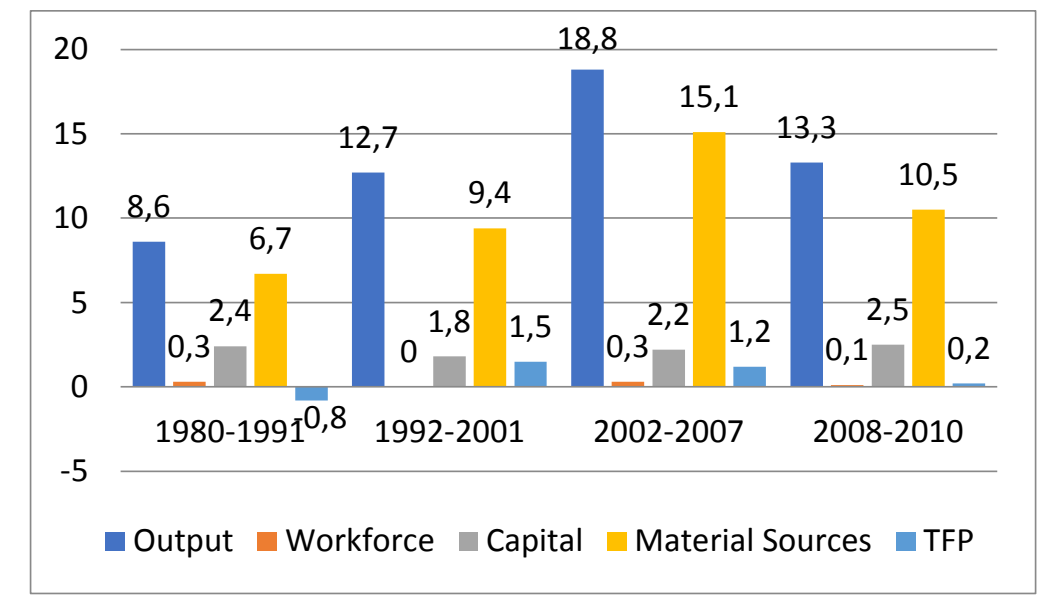

Graph 1. Total Estimation of China's Industrial Productivity Factor (in percent) Source: (Wu, 2014)

The weakness of productivity due to the old industry that is too dominating in the domestic market arena in turn creates a loss of comparative advantage in the labor sector. To overcome this, a theory on improving workforce quality postulates that in order to deal with excess of production capacity, the government should relocate industries previously employing a high amount of workforce to move out by looking for new markets abroad (Yu H., 2017).

Correspondingly, the central government has responded to this issue since 2007 by making it a national priority. However - this problem has not been resolved to its full potential. The central government often avoids these problems, because they contain sensitive political issues. Tom Mitchell and Yuan Yang (2016) see that failure to overcome excess production capacity requires a complete improvement in the model of state capitalism that has been run by China. If, the government overcomes the excess of production capacity, especially in the heavy industrial sector which has been dominated by SOEs, it has the potential to disrupt the stability of power in the CCP circle (Mitchell \& Yang, 2016).

The industry has also employed a sizeable workforce from the Chinese population. As such, overcoming this problem will also mean massively reducing the amount of workforce and increasing the risk of social disability as well as creating new gaps. This issue continued when GFC 2008 impacts mainland China. In 2016, China's economic slowdown requires the Chinese government to cut more than 1.8 million workers employed in heavy goods industry SOEs (1.3 million in the coal sector and 500 thousand in the iron and steel sector) (Yao \& Meng, 2016). In overcoming this problem, the government actually prioritizes the expansion of growth and maintaining employment without implementing structural reforms. The 
question then, what should the Chinese government do in the midst of an economic slowdown due to excess of production capacity?

The answer is the existence of BRI as a major program of China's foreign economic policy. This institution can mitigate domestic economic problems without having to take structural reform policies. This means that excess capacity can be relocated to external markets located along the BRI road. On the contrary, the Chinese government actually considers BRI's presence not as a will to facilitate domestic economic problems. They instead believe that BRI aims to increase regional and international industrial cooperation (Dollar, 2015). Apart from these denials, it is undisputable that BRI's presence has economic rationality from the domestic perspective, namely: (1) stimulating China's economic growth after GFC 2008; and (2) to become a new engine in creating greater market demand, especially for excess domestic production capacity, such as heavy goods (Huang, 2016; Cai, 2017; Rolland, 2017; Tekdal, 2018). Both can be achieved if combined with encouraging Chinese companies to move actively into the global market. In other words, BRI's presence was the most important instrument for the continuation of the internationalization of Chinese companies which had previously been held in Jiang Zemin's leadership.

Correspondingly, the Chinese government has acknowledged that the SOEs can play an important role in moderating China's economic slowdown. While from the SOEs' perspective, BRI is important for business development and expansion. The fundamental interest of business actors is the ease of allocating investment abroad, hence BRI is considered relevant to facilitate their business activities (Sze \& Wu, 2016). Herein lies the compatibility of general intrinsic goals between the central government and business actors in regard to BRI policies.

Chinese government paid great attention to business actors in implementing BRI in order to make SOEs an important entity in managing domestic economic development, as well as actively involved in expanding China's business network. In the beginning, the existence of SOEs has created social stability by offering uptake of labor and social services, bringing Chinese business interests to foreign markets, and growing China's technological and innovation base in the past few decades (Naughton, 2017). The presence of SOEs after Xi Jinping's election tends to be more controlled. This control is made through a hierarchical pattern of economic development, where SOEs respond to the will of the party and operate according to political will rather than following the logic of the market (Batson, 2016). In return, SOEs will get facilitated for business-based cooperation schemes in BRI-related program.

To elaborate, compatibility in this case can refer to the heart of the problem above - i.e. BRI's presence appears to be able to overcome domestic economic slowdown. This is possible by seeing that there is a gap to re-accelerate domestic economy which focuses on the infrastructure and transportation technology industry sectors, due to the saturation of the heavy equipment industry market and manufacturing which was caused by overcapacity problem. All of it has become part of the reason behind China's domestic economic slowdown. In addition, the infrastructure and transportation technology sector has essentially connected to BRI's vision as an instrument that serves global connectivity practices. This means that BRI's presence is substantially related to the effort to promote their SOEs in accordance with BRI's discourse, namely the ease of connectivity cooperation facilities. The authors shall elaborate in detail these two most important industries in the growth of contemporary China.

First, the infrastructure industry has become a new focus for the development and expansion of China's business after GFC 2008. This can be seen through the distribution of funding or incentives of the Chinese government in the face of economic recession. The policy milestone was named 'Stimulus Package', which was carried out to overcome the excess of 
domestic production of heavy iron, steel, cement and aluminum products (Dollar, 2015). This means that the infrastructure construction industry can absorb the excess of production capacity. Although the domestic market has been dominated by the infrastructure construction industry, the government has begun to realize that this industry must be included through the process of internationalization of Chinese companies. In other words, BRI's presence is a momentum for Chinese industrial companies to fill infrastructure development projects in several countries [along the BRI road]. The success of the Stimulus Package allocation to the infrastructure industry is illustrated through its contribution to contributing $22.6 \%$ of China's GDP - where the industry achieved a profit of RMB 7,586.4 billion (Zuo, Chan, \& Zhao, 2013).

Correspondingly, business actors engaged in infrastructure began to pay special attention amid the emergence of BRI. This can be proven through the research of Norman Sze and Flora $\mathrm{Wu}$ (2016) which examines the index of Chinese companies' participation and attention to BRI. This study found that BRI's presence was very relevant to 'the new age of internationalization' of Chinese companies. Furthermore, this study concludes that companies in the infrastructure and energy sectors have the same high interest and participation in BRI with a score of $24 \%$ (Sze \& Wu, 2016).

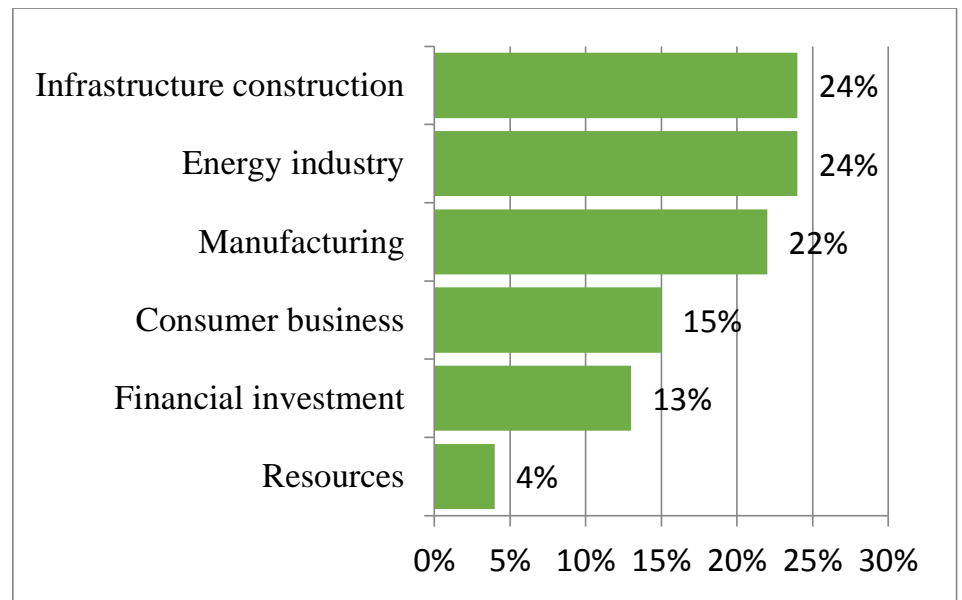

Graph 2. Category and distribution of Chinese SOEs in BRI Source: (Sze \& Wu, 2016)

Secondly, there is a serious effort from the Chinese government in promoting transportation technology, especially high-speed rails. Basically, China's railroad industry has developed and has become an important concern in the past few years. This industry has played a role in connectivity and driving economy over the past years. An analysis presented by Ralph William Huenemann (1984) illustrates that the construction of Chinese railways since several decades ago has contributed significantly to China's economic development agenda, especially in rural areas which has no access to water transportation (Huenemann, 1984). While Ernest P. Liang's findings revealed that the construction of railway has driven Chinese agriculture sector (Liang, 1982). Furthermore, railroad services also contributed significantly to stimulating business interactions between provinces, thus triggering domestic market competition while encouraging economic development (Supply, 1978). On that basis, the Chinese government continues to encourage the development of faster technology and 
capacity, so that it can increase the connectivity space of one region with other regions in China far more efficiently and effectively.

The emergence of central government programs focusing on railroad technology-based industry and innovation is a brilliant path, because it can mitigate the quality problems of domestic industries that have been dominated by manufacturing and heavy equipment. The Chinese government is targeting the development of high-speed rail innovation over the past two decaddes, because it is followed by an explosion in economic growth. In addition, the Beijing Administration has seen this type of industry as the future of China's economy (Wang, Liu, Mao, \& Sun, 2018). The government's attention to the development of railway industry quickly took place in two fundamental conditions, i.e, (1) the central government allocated the Stimulus Package to develop the high-speed rail industry after GFC 2008; and (2) the government influenced the market structure by the number of business actors involved in monopoly and oligopoly. Approximately $13 \%$ of the stimulus package which amounts to RMB 230 billion has been allocated to the development of high-speed rail industry (Yu \& Yang, 2011).

Later, Xi Jinping proposed a policy program for this industry as the focus of China's trade at the regional and international levels. This condition then provides an important advantage for China's high-speed rail companies with the presence of incentive and promotion facilities. In other words, the 'iron diplomacy' program becomes a new characteristic and key element of China's international relations and diplomacy. China's high-speed rail companies are gaining the most benefit out of this condition, despite being under state control. Compatibility between the government and high-speed rail companies can occur through BRI, where this industry can be easily promoted in various countries that are at the crossing of BRI road because the needs for high-speed rail service are important in creating quick and efficient mobility of people.

\subsection{Convergence of Interests of Central Government and Provincial Government}

Relations between the central government and the provincial government of China show fundamental changes since economic reforms and open door policies. At the beginning of economic reform, the relationship between the two units did not show a pattern of overall autonomy, since economic and political policy was dominated by the central government. It was only in the late 1970s that the early reformist leaders formed a pattern of interaction between the central government and the provincial government, in a semi-autonomous manner, such as allowing the provincial government to run a policy scheme that would allow farmers to sell their surplus products to available markets. This model shows a success, which has proven to be able to effectively increase productivity and prestigious economic growth at the provincial level (Heilmann, 2007). Furthermore, in the early 1980s, the provincial government gained legitimacy from the central government to carry out economic and fiscal programs without strict supervision. Local governments are permitted to maintain additional income from economic growth that is received if they meet the fiscal obligations previously determined by the central government.

This condition then has important implications for the interaction of the provincial government with local business actors. Because, the regional government considers that there are additional reasons to ensure that a company can be managed well and profitably, so that the implementation of business wheels is far more effective than being managed entirely by the central government (Huang, 1990). The provincial government becomes a "guardian" for 
local companies when ownership rights and other market institutions are not needed. In addition, the provincial government facilitates local companies, such as providing training, helping to secure access to resources, etc. Correspondingly, the relational pattern between the two has shown a concept called "regional government corporatism", where the local government seems to be the board of directors of local/subnational companies (Oi, 1995).

What should be highlighted here is the relationship between the central government and the provincial government appears to be federal relations, but it only takes place in the space of economic policy. Economic decentralization or, in Barry Weingast's (1995) words, 'market-preserving federalism', results in de facto federal system practices through economic management patterns. Provincial governments are under the control of the central government politically, but have a substantial function of autonomy and authority over the economy in their respective jurisdictions (Weingast, 1995).

On the contrary, there is a uniqueness in the political relationship between the two. For example, in order to maintain the influence and control of the central government to the provincial government, the CCP's elite ranks and the Beijing Administration have the authority in determining leaders and the process of succession of political office at the local level. In other words, relations in the political arena are centralized and hierarchical. This is done for the central government so that the CCP regime remains prominent in maintaining China's government (Xu, 2011). As a result, local officials compete with each other to develop the economy of their province in the hope of getting political rewards. Local governments that have succeeded in improving the provincial economy will be promoted again to lead other provinces that have experienced low economic performance or have the opportunity to lead strategic positions in the central government.

The position of the provincial government has become increasingly important for the central government since the open door policy was implemented. This relationship can mean that the provincial government is treated as an important actor in promoting and carrying out cooperation with regional countries, especially the Chinese provinces that are directly adjacent to countries in Southeast Asia, East Asia, Central Asia and South Asia. In addition, their awareness to expand China's network of economic and political interactions in neighboring countries is also due to the presence of economic decentralization. This means that the provincial government is a vital part in translating the central and strategic political interests of the central government into several regional countries. These provinces, such as Xinjiang [Northeast China region], Yunnan [Southwest China region] and Guandong [China's coastal region].

Xinjiang Province has become the heart of China's interaction with Central Asia and Europe. Initially, the central government positioned Xinjiang as an area that serves China's supply of energy and mineral resources. Later, this region was developed into an energy transmission corridor between China and Central Asia. After that, Xinjiang grew into an important part of China's economic development, so it was known to be a bridgehead for China's openness and expansion in the regional structure (Toops, 2016). As such, Xinjiang province not only facilitates central government interaction with Central Asian and European countries, but also becomes the heartbeat of national energy.

Yunnan Province helped facilitate the interests of the central government regarding the regionalism agenda in Southeast Asia. This is increasingly felt since China has become a proactive country in organizing trade, investment and infrastructure development assistance missions by integrating Yunnan province with various external state provinces involved in the Mekong Economic Corridor cooperation ( $\mathrm{Su}, 2012)$. This area has China's strategic economic and political interests - as a spearhead of strategic political battle that involves China, Japan 
and the US. To gain an important position before the Mekong countries, China channeled assistance in infrastructure development as an instrument of economic development in the form of intensive development and deepening economic cooperation. In other words, the involvement of the Yunnan provincial government is not just facilitating the central government to reach economic interests such as the natural resources owned by the Mekong region, but also as a liaison of China to deepen connectivity between China and Southeast Asia and limit Japan and US strategic interests (Yoshimatsu \& Trinidad, 2010; Reilly, 2013).

Guangdong Province also contributes greatly to running the maritime economy in the free market area with surrounding countries. The concept of maritime economic policy is a regional government program that took place since 1993 with the emergence of a maritime industrial area. In 1998, the eighth CCP Congress ratified the policy recommendations offered by the Guangdong government, namely making Guangdong the base of the maritime economy. After that, in the 2000s the central government projected the province as a maritime economic region through the plan of four major industries, namely: fisheries, tourism, maritime transportation traffic, and maritime industry engineering. Then, in 2011 the Chinese Council ratified Guangdong's development plan as a comprehensive pilot of China's maritime economy, hence President $\mathrm{Hu}$ Jintao instructed that the province must use maritime resources to facilitate China's economic growth. The plan considers two important things, namely: (1) maritime as a new axis for provincial and central economic development; and (2) the regional government policy program is continued by the central government as a national agenda towards global maritime power (Martinson, 2014).

The context above shows a characteristic of the implications of the relationship between the central government and the provincial government, that the provincial government has become a servant to the interests of pragmatic economic development at the local level, while facilitating the various strategic interests of the central government to neighboring countries. This process has continued since the election of $\mathrm{Xi}$ Jinping to reactivate the role of provinces to be integrated in deeper economic cooperation relations with neighboring China. The authors believe that BRI proposals take place as a national major program, which summarizes all the experiences carried out by the provincial government in serving economic reform programs and open door policies. In return, the central government formed an action plan for megaregional cooperation through the agenda of connectivity and integration as its pulse. The three examples of provinces that have already been mentioned - have contributed to the formulation of Chinese connectivity initiatives called the New Silk Road, namely: (1) Xinjiang province will become a center to connect China through Central Asia to penetrate Europe; (2) Yunnan province will be the centric that connects China to mainland Southeast Asia; and (3) Guangdong province will be a centric that connects China with several regions in East Asia and Southeast Asia through the maritime axis.

Apart from the desire of the three provinces to be a center, the BRI program launched by the central government did not exclude the role of other provinces. As a result, each province has a balanced and centric position if it is compatible with the BRI program. Great attention and participation have been presented by every province of China since the emergence of the BRI initiative. For the provincial government, the policy is as a way to plan their economy with the central government and provide substantial benefits to subnational companies. Utilization of funding facilities from the central government for BRI has been envisioned by local governments as an opportunity to ensure the continuity of economic growth in overcoming the national economic slowdown. Regional government attention to BRI's implementation has been increasing since the Chinese National Reform and Development Commission launched the BRI White Book in March 2013 (Beauchamp-Mustafaga, 2015). 
The document explicitly explains the intentions, objectives, principles, framework of consideration, priorities and mechanisms of cooperation, and actions of unification between local governments and the central government to pursue China's Go Out strategy through BRI (NDRC, 2015). As such, this document contains procedural steps to reactivate the provincial government to pursue development targets in a coordinative, effective and centralized manner. To put it in another perspective, BRI's presence shows a convergence of interests between the central government and local governments. On the one hand, the central government can make the provincial government an important actor in facilitating China's strategic interests before neighboring countries. On the other hand, the provincial government responded to BRI's presence as a continuation of their experiences since the open door policy resulted in prestigious gains in economic growth in the past few years.

\section{FORM OF STATE CONTROL: INFRASTRUCTURE AND TRANSPORTATION COMPANIES}

SOEs have far closer relationship to the Chinese government compared to private companies. The Chinese government tries to carry out more complex forms of interaction with business actors, so that they can control them in a more coordinative and directive manner. The controlling relationship between the state and SOEs takes place in four circumstances, i.e.: (1) control over exchange rates, taxes, regulations, and business licenses and permits; (2) allocation of subsidies, credit and insurance through central banks and development banks, which are often needed for large business activities abroad; (3) nomenclature system, in which the Organization Department of Chinese Communist Party and the State-owned Assets Supervision and Administration Commission (SASAC) appoint the highest leader of an SOE; and (4) controlling pattern over SOEs other than institutional forms such as ideological apparatus where the relationship of the two is carried out through the responsibility system of CCP cadre (Jones \& Zhou, 2017). However, to show the implementation of these four actions, the authors will explain them in two forms of application, i.e. understanding what the market structure has been formed by the state, and the reporting relationship between the government and SOEs. These two questions will be more focused on infrastructure companies and railway companies.

\subsection{Market Structure}

The presence of market players for the infrastructure and transportation industry sector in China has shown a form of monopoly under the control of the central government. This is marked by the emergence of SOEs that have assets and experience that are able to compete in the domestic and external markets. For companies engaged in infrastructure, it is dominated by SOEs called China Communications Construction Co. Ltd. (CCCC). CCCC has been chosen by the Chinese government to focus as a company that specifically works in dredging and port construction.

The government paid a great attention to CCCC based on various fundamental considerations. The presence of CCCC began as early as the Qin Dynasty, when Emperor Guangxu ordered the formation of Junpu Technical Bureau in 1905 (Zhang \& Alon, 2010). During the mid-20th century, the bureau had established four important corporate entities, namely Port Construction Co. (1-4) under the control of China Communications Company. 
The company survived until the 1970s and worked not only in port construction, but also in research, design and planning of highway.

Then, in the late 1970s, the government added companies to the infrastructure construction industry, namely China Road and Bridge Corporation (CRBC) and China Harbor Engineering Group Corporation (CHEC). For the management of various companies in a homogeneous field, the central government appointed the Ministry of Development and Infrastructure of China (MDIC) to oversee and facilitate the needs of China's infrastructure construction industry. With this opportunity, the management of the industry in this area was far more effective, signified by MDIC forming two groups of companies to consolidate the assets of state ownership of all these companies, namely highway constructor and port constructor.

It was only in 2005 that the government managed to "mega-merge" the two groups of companies that previously had different work specifications. This unification then ended with CCCC as the sole SOE engaged in the infrastructure industry. Officially, CCCC was listed on the Hong Kong stock exchange on October 8, 2006. Despite being new, the two companies have participated actively in the global market in the past two decades. At present, CCCC has become a multinational company presence in 40 countries around the world.

Later, CCCC also carried out industrial services, for example dredging projects facilitated by two of its subsidiaries, namely China Harbor Engineering Company Limited and China Road and Bridge Company Limited. Despite having various subsidiaries, CCCC maintains a centralized management system - exactly like the CCCC under SASAC. This condition has illustrated that the market structure for infrastructure construction industry is monopolized by CCCC because of the government's efforts to provide specialization and incentives.

The same monopolized market structure can also be found in the market structure for highspeed rail industry. State control for this industry takes place in two types of companies, each of which has a focus and specialization, namely: (1) technology development industry and high-speed rail facilities; and (2) the service industry which offers cooperation contracts for the construction of high-speed rail projects. Despite having different circumstances, both of them still show a symbiotic relationship in China's high-speed rail industry expansion.

Companies engaged in the first field have been equipped with technical work experience due to the transfer agreement with high-speed rail corporations from Alstom (France), Siemens (Germany), Bombardier (Canada), and Kawasaki Heavy Industry (Japan). This shows that the central government has paid great attention to the development of China's highspeed rail industry. In 2004, the Chinese Ministry of Railways appointed two SOEs focusing on the railroad sector, namely China South Rail (CSR) and China North Rail (CNR) to work with foreign technical partners to produce a much more innovative high-speed rail product.

The agreement resulted in the production of electric multiple units, namely $\mathrm{CRH}-1$ to CRH-5. The CRH-1 series production involved CSR and Bombardier by producing 40 product versions, each with a maximum speed of $250 \mathrm{~km} /$ hour. The CRH-2 series involves a CSR under Kawasaki license to design the E2-1000 Shinkansen series by producing 56 product versions with speeds of $250 \mathrm{~km} / \mathrm{h}$ and $300 \mathrm{~km} / \mathrm{h}$ respectively. CRH-3 was produced by CNR under Siemens license by producing eight product versions with speeds reaching $350 \mathrm{~km} / \mathrm{hour}$. CRH-5A is produced by CNR under a license from Alstrom which produces eight product versions with maximum speed reaching $250 \mathrm{~km} /$ hour (Lee, 2016, pp. 204-205).

China has set technical specifications related to high-speed rails, where the railroad industry for the high-speed rail sector claims that the ratio of local content is more than $80 \%$. After the transfer of this technology was successful, the Chinese government then conducted a "mega-merger" for two companies engaged in the same sector to become China Railway Rolling-Stock Co. Ltd. in mid-2015. This union shows that the market structure for the 
development of high-speed rail facilities that were originally duopoly became more concentrated or monopoly because it only involves one company. In other words, the Chinese government has made CRRC the sole company in the technology development and high-speed rail infrastructure.

While the company focused on completing the high-speed rail project took place at two SOEs, namely China Railway Construction Corporation (CRCC) and China Railway Group Ltd (CRG). Although it takes place in the market structure with the duopoly model, it does not mean that the country has difficulty controlling them. The control originated from the government's efforts to close the competition between the two with the strategy of completing the high-speed rail project at the domestic and foreign levels.

The high-speed rail construction project at China's domestic level is classified through four types of development. First is the construction of high-speed rails based on passenger designated lines - which only carry passenger services. The second is the construction of highspeed rails that can carry freight trains that are specifically for the western part of China. The third is a high-speed rail that connects between cities with long distances that are intended for passenger services. The last is conventional trains that have been upgraded to speed acceleration to transport passengers and cargo goods(Lee, 2016).

Overall, of the four types of high-speed rail construction are operated by CRCC. The company has a specialization for the completion of high-speed rail projects that involve domestic level routes and facilities. While CRG is a Chinese multinational company that focuses on filling out cooperation contracts for high-speed rails in various countries. With the presence of BRI, high-speed rail companies have opportunities to fill in various development cooperation contracts in various countries. Obviously, BRI is an effective platform for the internationalization of China's high-speed rail SOEs.

\subsection{Reporting Relations}

In the analytical framework offered by Norris, reporting relationship between business actors and the government is an essential variable to test how far the state controls its companies. SOEs are the only company that gets more complete attention from the state, so the opportunity for state control is far greater than that of private companies. This is because they have become part of the government structure, hence the incentives in turn form a counter-effect both from the government side and from the company leadership (Norris, 2016, p.33). For example, the government provides a large source of funding or subsidy to the company, while the business actors need the company to be able to win strategic infrastructure contracts in various countries. For this reason, the authors will elaborate on the kind of reporting relationship between the government and companies engaged in the infrastructure and railroad construction industry.

As mentioned above, the process of state control for the infrastructure industry is considered successful in the arena of domestic markets and international markets. In December 2013, CCCC had total assets of USD 122,154 million, then climbed sharply in 2016 with total assets of USD 894,145.40 million (Nikkei Asian Review, 2018). The company has 30 subsidiaries, each of which has industrial work specifications in line with CCCC's focus as a state-owned transportation infrastructure. Chief among them are infrastructure construction, dredging and heavy machinery manufacturing business. There are many aspects of the business, namely ports, terminals, roads, bridges, trains, tunnels, reclamation, container cranes, export and import trade services, steel structures and road manufacturing, heavy ship 
engines, and international project contracts. Unsurprisingly, the company has become a leading SOE in recent years and has become a fierce competitor for US multinational corporations called Stantec Inc.

To facilitate the reporting relationship between CCCC and the central government, SASAC gained authority in appointing the leaders of this company with very high specifications. They are not only appointed based on their reputation or experience in leading SOEs in other sectors, but also their reputation or experience in academic world. For example, Qitao Liu, who served as Executive Chairman of the CCCC SOEs Board since 2013, has great dedication to the CCP, because he is listed as a CCP cadre. In recent years, Qitao has become a Deputy General Manager in the energy sector SOE named China National Water Resources and Hydropower Engineering Corporation since 1997-2003. Then he became General Manager and Director for the Chinese multinational SOEs named Sinohydro Group Ltd from 2009-2010. In the academic field, he is also renowned as an expert professor or equivalent to senior engineers and receives important awards given by the State Council (Reuters, 2018).

SASAC's choice in appointing Qitao Liu as the leader of CCCC's company was considered appropriate and brilliant. After all, during his leadership, Qitao has succeeded in bringing CCCC into a multinational company capable to compete in global market arena by occupying the world's first position as a construction and transportation infrastructure development company. In 2017, CCCC's total asset value reached USD 1,020.66 billion and its total equity was USD 211,646.46 million (Nikkei Asian Review, 2018). This success is obviously the result of reporting relationships and compatible material resources between the company and the central government. To develop the company's achievements, CCCC's board members are willing to carry out a managerial pattern directly from SASAC and the State Council. As a form of dedication to national development, this company adopted China's national vision "Chinese Dream" by using the word "CCCC's Dream" (Qitao, 2018). In addition, the company also facilitates China's foreign economic policies through BRI as China's global mission by consolidating the connectivity program and eliminating boundaries between one region and another.

The reporting relationship between the state and high-speed rail companies is also similar as CCCC. This can be seen through companies engaged in the production of high-speed rail materials, namely CRRC, CRG, and CRCC which acts as a service company for the completion of high-speed rail contract (constructor). The reporting relationship among these three companies is hierarchically directive because they are SOEs and are part of state institution. In other words, CRRC, CRG, and CRCC have been designed to be specialized companies for certain sector - hence the reporting relationships [company ownership, company management, and financing structures] are controlled by the state.

China Railway Rolling-Stock Co. Ltd (CRRC) is an SOE that has been appointed directly by the state council, which focuses on the sector or field of development of railroad technology and facilities. CRRC supervised various subsidiaries with different categories of railroad construction and facilities. The locomotive workmanship category is carried out by seven companies, including the CRRC Datong Electruc Locomotive, CRRC Qushuyan Locomotive, and CRRC Xiangfan Locomotive. While the category of rolling stock is carried out by several subsidiaries, namely CRRC Meishan Rolling Stock, Nanjing CRRC Puzhen Rolling Stock, etc. In order to run this company in accordance with the interests of the central government, SASAC has appointed the highest CRRC company leader named Hualong Liu. Hualong's choice cannot be separated from the his experience in leading the company and his career as a CCP cadre. Since 2012, Hualong has received the mandate to become the Deputy 
Secretary of the CCP. For example, he served as Deputy Manager for Qiqihar Rolling Stock Works which is a company under the control of the Ministry of Railways since 1998 to 2001. In the following year he served as General Manager of Qiqihar Railway Rolling Stock (Group) Co. Ltd. before being appointed to lead the CRRC (Bloomberg, 2018).

The direct control of the state on CRRC through the company's ownership and managerial arrangements aims to create a direct and beneficial reporting relationship for the central government. Although its business activities are controlled by the state apparatus, this company still managed to become a multinational company. One of the greatest achievements of CRRC is becoming the largest company in the world in supplying the rolling stock manufacture of high-speed rails (Smith, 2017). CRRC has even become a fierce competitor for the French High-Spped Rail multinational company, Alstom SA - a company which used to transfer railway technology and manufacture to CNR company.

The central government's control on CRRC can be seen by the government owning $60 \%$ of its share and providing subsidies amounting to USD 484 billion (New York Times, 2013). As a result, the CRRC policy has been adjusted to be compatible to China's national policy. The company's focus takes place in three main arenas, namely innovation, reform, and internationalization. The goal is to drive the CRRC to carry out in-depth reform methods such as those carried out by the government, namely to move the innovation engine and the spirit of sustainability and strive to become a world-class multinational company (CRRC, 2016). In other words, to enter the ranks of the world's corporate elites, the CRRC needs central government incentives, especially regarding the continuity of China's internationalization strategy.

Meanwhile, the reporting relationship of railroad constructor service companies, i.e. China Railway Construction Corporation (CRCC) and Railway Group Limited (CRG) to the government shows the same pattern as the CRRC. China Railway Construction Corporation (CRCC) is a constructor of railways that provides two services, namely the construction of conventional and high-speed rail projects. As in the previous discussion, this company has been designed by the government to become a company responsible for completing railway projects in China. Since the SOE reform in 2007, the ownership of SASAC over CRCC has been $60 \%$. This is done so that CRCC can become a multinational company that is open to the investment market. Despite being a public company, the Chinese government maintains its control efforts through the domination of share ownership.

In return, the central government has projected CRCC as a company that must be be involved in various high-speed rail projects abroad. As with other SOEs, the appointment of CRCC leadership remains to be determined by SASAC. In addition, the reporting relationship for high-speed rail companies tasked to bid cooperation projects in the external market shall be carried out first and foremost by China Railway Group Limited (CRG). Share ownership for this company has been completely dominated (100\%) by SASAC. As a result, state control is increasingly significant for CRG business activities. At present, CRG has become the largest multi-functional construction company in China and the largest in Asia based on its revenues and assets. As with the companies described above, the reporting relationship between the government and CRG is increasingly dominant, because the appointment of the company's leadership is carried out by SASAC. Despite being appointed in a closed manner the board of directors has shown success in increasing revenue growth and company expansion. In a release from Nikkei Asian Review report, CRG had a significant leap in total assets from merely USD 804,590.40 million in 2013 to USD 851,766.52 million in 2015 (Nikkei Asian Review, 2018). 


\section{BRI IMPLEMENTATION IN SOUTHEAST ASIA}

Further discussion in this section aims to see the implications of Chinese government's control of SOEs in infrastructure and transportation (high-speed rails) that take place at the domestic level. This section also aims to show that those implications can be relevant for the implementation of BRI programs in various countries.

Norman Sze and Flora Wu's (2016) research mentions a poll among Chinese businessman which places Southeast Asia as a priority area for investment in infrastructure and transportation sector. The participation index was 53\% for Southeast Asia and $47 \%$ for South Asia (Sze \& Wu, 2016, p. 15). This high attention is based on an understanding that Southeast Asia's economic growth has increased, but is fragmented by the limitations of physical infrastructure facilities that often become a stumbling block in economic and trade connectivity. This is an important opportunity for Chinese SOEs to widen their business wings in facilitating the completion of physical infrastructure projects.

Physical infrastructure has become an important capital in the deepening process of economic integration in Southeast Asia. In fact, the availability of physical infrastructure at the regional level will be a determinant factor to influence the cycle of demand, productivity and higher growth in order to achieve the long-term development goals of ASEAN economic regionalism (Bhattacharyay, 2009). However, infrastructure projects and access to regional transportation are considered weak.

Oftentimes, several plans to work on infrastructure projects carried out by ASEAN experience stagnation. One of the examples is the development of ASEAN Highway Network (AHN) which was agreed in 1999. AHN was projected to connect 23 transnational roads which are targeted to be completed by 2020 , with a total length of $38,000 \mathrm{~km}$. The target of this project will be of Class I level, as it was designed to construct new route between Myanmar, Laos, Vietnam and Cambodia. According to the 2016 World Bank Group study, it was stated that around $70 \%$ of lost roads had been rebuilt in Myanmar, but this project was still below the Class III level (not yet paved). The AHN route was then expanded by 2,559 km or 10.6\% between 2010-2015. Expansion of AHN concentrations occurred in Cambodia, Myanmar and Vietnam but it was still of Class III level (WBG, 2016, p. 40). Thus, the progress and continuation of this project often changes and is not in line with expectations in creating quality land transportation access.

The same can also be said on the development of maritime transportation infrastructure in Southeast Asia. This development was carried out despite the minimum availability of port logistics. As a result, the burden for transportation and logistics costs is quite large in intraregional trade, compared to trade between ASEAN member countries and ASEAN partner countries. The weak quality of the port logistics is true in almost all of ASEAN member countries. The Logistics Performance Index released by the 2014 World Economic Forum shows that the Philippines and Indonesia are ranked 95 and 72, lagging behind Singapore (ranked 5), and Malaysia (ranked 20), but ahead of Vietnam (ranked 112), Laos (ranked 66), Cambodia (ranked 109), and Myanmar (rank 138) (Hong, 2017).

One of the main factors that make these projects unrealized or require a long time to complete is a huge funding burden. According to $\mathrm{ADB}$, the Asian region requires an investment of USD 8 trillion for domestic infrastructure and USD 290 billion for the development of intra-regional infrastructure in 2010-2020 to realize more optimal economic growth. Each ASEAN country such as Indonesia, Thailand, Malaysia, and the Philippines will require investments of up to USD 550 billion in 2013-2020. While railroad transportation infrastructure requires an investment of USD 119 billion (Hong, 2017). As a result, the 
realization of intra-regional infrastructure faces fundamental problems in terms of financing development and completion of transportation infrastructure projects. ASEAN requires at least USD 60 billion annually to develop transportation infrastructure both on land and in maritime. In reality, ADB which has been the main supporter of the ASEAN Connectivity Program actually has a borrowing threshold of USD 13 billion per year (ADB, 2016).

Looking at these conditions, China gained momentum to continue its influence which has been important for the political economy dynamics in Southeast Asia. Long before the promotion of BRI, as well as the Maritime Silk Road Initiative in Indonesia, China has become one of the countries that is quite active in promoting development and connectivity cooperation in Southeast Asia. This is done so that China can be seen as a country that has a peaceful rise and prioritizes mutually beneficial cooperation. The attitude of Chinese foreign policy is then specified in the 'good neighbor policy' in Southeast Asia by referring to three principles, namely mutual security, mutual cooperation, and mutual development (Tai \& Soong, 2014). It is important to understand that this orientation is not only to strengthen economic relations, but also as a form of effort in promoting China's strategic political interests - as the state has an important position and influence in the regional and international political economic structure.

The authors argue that China has positioned Southeast Asia as an area with the most productive and receptive potential to project its influence. In this case, building physical connectivity with Southeast Asian countries is a surefire way to accelerate China's export share, while increasing its influence on strategic political needs. The main key of connectivity is to build complex interactions in both the political and cultural economic dimensions, so that operational networks, especially transportation infrastructure, will make the regional community familiar with China's economic interests. For example, the presence of the Great Mekong Sub-region (GMS) is expected to accelerate economic growth and the quality of physical and non-physical infrastructure between China and Vietnam, Laos, Cambodia, Thailand, and Myanmar. On the other hand, however, this has the tendency to create friction among ASEAN countries. As a matter of fact, the presence of sub-region cooperation involving several Southeast Asian countries has a potential to deepen ning ASEAN economic regionalism.

This is argument was made based on four factors. First, the strategic objective of this model of cooperation is complementary in the ASEAN connectivity mission by focusing on inter-subnational development. Second, this collaboration can form building blocks in the infrastructure sector. Third, this cooperation project can stimulate economic regionalism which is far more open through efforts to establish cooperation outside the regional countries. Finally, as an alternative way to reduce development gaps that occur within the region, state, and sub-national scope (Pomfret \& Das, 2013). Geoff Wade believes that the development of transportation infrastructure in GMS has contributed more to improve connectivity between some ASEAN countries and China, compared to ASEAN's own intra-regional connectivity (Wade, 2010). This assumption is an antithesis from the previous view which believes that the presence of sub-regional cooperation programs can facilitate the deepening process of ASEAN integration. China managed to become very active in connectivity cooperation in the Mekong region due to the decreasing allocation of ADB financing for infrastructure programs. This is a momentum for China to deepen its relations with Southeast Asian countries, with a model of connectivity cooperation - by mutually facilitating the development of advanced transportation infrastructure on one hand, and making China the center of mainland Southeast Asia on the other hand. It can be said that China is unsatisfied by only prioritizing connectivity cooperation that involves few Southeast Asian countries as they began to focus on investing in 
the infrastructure and transportation sectors in all Southeast Asian countries. In 2012, China's investment was only USD 275.47 million in construction sector and USD 1,722.46 million in transportation sector. Then, in 2016, they invested USD 751.37 million in construction sector and USD 2,181.83 million in transportation sector.

The increasing amount of investment above was influenced by the implementation of BRI program in Southeast Asia. Southeast Asian countries have shown concern in welcoming the presence of BRI, where they both need facilities for cooperation in infrastructure and transportation development. This is done given that some Southeast Asian countries carry out populist policies to boost economic growth caused by the availability of adequate and inexpensive infrastructure and transportation facilities. Even so, this cooperation program is not only valuable for business cooperation, but is also contributive in promoting China's strategic political interests in Southeast Asia. As such, in order for Beijing to gain two benefits at once, they will need their business actors, especially in infrastructure and transportation. This dictum can be observed through the implementation of BRI in the Philippines and Indonesia.

\subsection{Philippines}

The acceptance of the BRI program in the Philippines has had a significant influence on a more fluid relationship between the Philippines and China. Reflecting on the leadership of President Aquino III, the BRI program initially did not receive warm welcome because China had been blacklisted as a maritime enemy due to territorial dispute in the South China Sea. The fluid relationship between China and Philippines can only be observed after the leadership of Rodrigo Duterte in 2016. This was marked by his attitude of accepting institutional cooperation offered by China, namely BRI. The reason for Duterte's decision is the inherentness of the BRI program, namely vision of connectivity, which goes hand in hand with his focuses on accelerating the development of domestic infrastructure.

In addition, Duterte also realizes that poverty and domestic economic slowdown still haunt the Philippines in recent years, so the Manila Administration established the Ten SocioEconomic Agenda programs to reduce poverty from $21.6 \%$ to $13-15 \%$ in 2022 . To achieve the target, the Philippines government launched a development reform program that included the availability of physical infrastructure and industrial development through the "Build, Build, and Build" program. Rodrigo Duterte emphasized that this policy aims to achieve the "Period of Infrastructure Security", on the basis that mobility and connectivity have logical consequences to increase economic growth (Venzon, 2018). To finance infrastructure projects, the Chinese government needs $20 \%$ of loans from foreign investors while the rest comes from domestic loans. Herein lies the opportunity for Chinese business actors to continue to improve China's diplomatic relations through BRI as a connectivity agenda, while also gaining momentum to expand their business networks and activities in the Philippines.

In carrying out infrastructure and transportation cooperation involving Chinese companies, there are two strategic projects implemented: (1) Davao Coastline and Port Development (DCPD); and (2) Mindanao Railway Project (MRP). Financing scheme for both projects is carried out through government and private partnership. The value of the DCPD project is PHP 24.5 billion. However, the involvement of new Chinese companies was agreed to complete the reclamation project which is also a large part of the DCPD project. The Chinese company involved was CCCC with an investment of USD 0.8 billion. While the projected MRP project has a track of 2,000 kilometers which will connect the main cities of Davao, 
Zamboanga, Butuan, Surigao, Cagayan de Oro, Iligan and General with funding needs of PHP 128.1 billion. So far, the Chinese government has agreed to sign for the construction of a $1,200 \mathrm{~km}$ railway line that connects Davao to Cagayan de Oro with completion targets until 2022 carried out by China Railway Eryuan Engineering which is a subsidiary of CRCC (mindanao.politics.com.ph, 2017).

\subsection{Indonesia}

The presence of connectivity agenda promoted by Xi Jinping through BRI received a major response from the Indonesian government. This refers to the convergence of BRI connectivity mission with Indonesia's policy focus, namely the acceleration of the availability of physical infrastructure development in various parts of Indonesia (Pradhan, 2016; Pitlo, 2016). Under the leadership of Joko "Jokowi" Widodo, it has been emphasized that the completion of infrastructure and transportation services projects shall be derived from nonstate budget (APBN) funding. Hence, the Indonesian government needs funding facilities both from investment and loans from other countries. This is the moment where China gains its momentum to deepen economic and political relations with Indonesia. From a series of Indonesian strategic projects involving China after BRI promotion, there is one project that is important to be observed because it contains strategic economic and political implications of China through the involvement of business actors.

The Jakarta-Bandung High-Speed Rail (Kereta Cepat Jakarta-Bandung/KCJB) project is a business-to-business construction cooperation, where the financing came from a consortium involving Chinese companies (CRCC) and Indonesian companies, as well as loans from China Development Bank. This project is targeted for completion by 2021, with capital requirements reaching USD 6.071 billion. The large funding needs were accompanied by high-speed rail technology along the route which reached $142 \mathrm{KM}$. Initially, this project originally involves Japanese companies - which are known as one of the most prominent countries for high-speed rails production. However, the agreement only lasts until the implementation of feasibility study. Shortly after, Xi Jinping won a bid to facilitate the financing of the project, which also means that the standard, technology, and equipment for the project shall be prepared by China. This acceptance was of course accompanied by the presence of BRI which received important attention from the Jakarta Administration. The KCJB project is indeed of strategic value because China tends to accentuate its image as an industrial country capable of producing state-of-the-art high-speed rails despite being a new player in the competition. In addition, the opportunity to complete KCJB is an important capital for the acceptance of China's high-speed rail industry in Southeast Asian countries.

\section{CONCLUSION}

Based on the findings and analysis that have been explained, the authors affirm that the connectivity agenda through BRI contains China's strategic economic and political rationality at the Southeast Asian level. All of them run integrally due to the success of the state in controlling business actors at the domestic level. This can be proven by the involvement of Chinese companies in creating homogeneous cooperation contracts in Indonesia and the Philippines. The service for the construction of roads, ports and other supporting infrastructure is carried out by China Communications Construction Company Limited (CCCC Ltd), while 
the [high-speed-rail-dominated] railroad system is carried out by China Railway Construction Corporation (CRCC).

\section{ACKNOWLEDGEMENT}

This research based on grant scheme of PITTA (Publikasi International Terindeks untuk Tugas Akhir) or also known as Indexed International Publications for Final Projects toward Universitas Indonesia students. Thank you to Asra Virgianita as my advisor and thank you to The Directorate of Research and Community Engagement of Universitas Indonesia (DRPM UI).

\section{REFERENCES}

[1]. ADB. (2016). ASEAN Infrastructure Fund. Retrieved April 31, 2018, from https://www.adb.org/site/funds/funds/asean-infrastructure-fund

[2]. Aoyama, R. (2016). "One Belt, One Road": China's New Global Strategy. Journal of Contemporary East Asia Studies, 5(22), 3-22.

[3]. Batson, A. (2016). Villains Or Victims? The Role of SOEs in China's Economy. China Economic Quarterly, 20(2), 7-14.

[4]. Beauchamp-Mustafaga, N. (2015). Chinese Provinces Aims to Find Their Place Along New Silk Road. China Brief, 15(10), 1-3.

[5]. Bhattacharyay, B. N. (2009). Infrastructure Development for ASEAN Economic Integration. Tokyo: ADB Institute.

[6]. Bloomberg. (2018). CRRC Corp Ltd. Retrieved May 21, 2018, from https://www.bloomberg.com/research/stocks/people/person.asp?personId=53973458\&p rivcapId $=12188205$

[7]. Callaghan, M., \& Hubbard, P. (2016). The Asian Infrastructure Investment Bank: Multilateralism on the Silk Road. China Economic Journal, 9(2), 116-139.

[8]. Cendrowski, S. (2015, July 22). China's Global 500 Companies are Bigger than everand mostly State-Owned. Retrieved August 13, 2018, from Fortune.com: http://fortune.com/2015/07/22/china-global-500-government-owned/

[9]. China.org.cn. (2014). Decision of the Central Committee of the Communist Party of China on Some Major Issues Concerning Comprehensively Deepening the Reform. Retrieved May 20, 2018, from http://www.china.org.cn/china/third_plenary_session/201401/16/content_31212602.htm

[10]. Clarke, M. (2017). The Belt and Road Initiative: China's New Grand Strategy? Asia Policy, July(24), 71-79.

[11]. CRRC. (2016). Connect Hearts Connect the World. Hong Kong: CRRC.

[12]. Cung, C. (1978). An Outline of Chinese Geography. Peking: oreign Languages Press.

[13]. Dollar, D. (2015). China's Rise as a Regional and Global Power: The AIIB and the One Belt, One Road. Horizons(4), 162-172.

[14]. Downs, E. (2014). Business and Politics in the SouthChina Sea: Explaining HYSY 981's Foray into Disputed Waters. China Brief, 14(12), 6-8.

[15]. Duval, Y., \& Feyler, E. (2016). Intra- and Extraregional Trade Costs of ASEAN Economies Implications for Asian Regional Integration. In B. Jetin, \& M. Mikic (Eds.), 
ASEAN Economic Community: A Model for Asia-wide Regional Integration? (pp. 153-172). Basingstoke: Palgrave Macmillan.

[16]. Feng, E. (2016, October 13). Xi Jinping Reminds China's State Companies of Who's the Boss. Retrieved from New York Times: https://www.nytimes.com/2016/10/14/world/asia/china-soe-state-ownedenterprises.html

[17]. Gjoza, E. (2017, July 13). Today's Chinese Foreign Policy Is All Business. Retrieved August 3, 2018, from The National Interest: https://nationalinterest.org/feature/todayschinese-foreign-policy-all-business-21530

[18]. Gonzalez-Vicente, R. (2012). Mapping Chinese Mining Investment in Latin America: Politics or Market? The China Quarterly, 209, 35-58.

[19]. Heilmann, S. (2007). Policy Experimentation in China's Economic Rise. Studies in Comparative International Development, 43(1), 1-26.

[20]. Hong, Z. (2017). "One Belt One Road" and China-Southeast Asia Relations. In L. Dittmer, \& C. B. Ngeow (Eds.), Southeast Asia and China: A Contest in Mutual Socialization (pp. 211-225). Singapore: World Scientific Publishing Co. Pte. Ltd.

[21]. Hong, Z. (2016). China's One Belt One Road: An Overview of the Debate. Singapore: ISEAS Publishing.

[22]. Huang, Y. (1990). Web of Interests and Patterns of Behaviour of Chinese Local Economic Bureaucracies and Enterprises during Reforms. The China Quarterly, 123, 431-458.

[23]. Huenemann, R. W. (1984). The Dragon and the Iron Horse: The Economics of Railroads in China, 1876-1937. Massachusetts: Harvard University Press.

[24]. Ikenberry, J. G. (2012). The rise of China, the United States, and the Future of the Liberal International Order. In 53-73 (Ed.), Tangled Titans: The United States and China (pp. 53-73). New York: Rowman \& Littlefield Publishers.

[25]. Jianren, L. (2016). The 21st Century Maritime Silk Road and China-ASEAN Industry Cooperation. International Journal of China Studies, 7(3), 375-389.

[26]. Jones, L., \& Zhou, Y. (2017). Rethinking the Role of SOEs in China's Rise. New Political Economy, 22(6), 743-760.

[27]. Junxian, G., \& Yan, M. (2016). China's New Silk Road: Where Does It Lead? Asian Perspective, 40(1), 105-130.

[28]. Lee, H. C. (2016). Prospect of Chinese Rail Export Under “ One Belt, One Road. In L. T. Wei, H. C. Lee, K. T. Hui-Yi, \& L. W. Xin, China's One Belt One Road Initiative (pp. 197-235). London: Imperial College Press.

[29]. Len, C. (2015). China's 21st Century Maritime Silk Road Initiative, Energy Security and SLOC Access. Maritime Affairs: Journal of the National Maritime Foundation of India, 11(1), 1-18.

[30]. Liang, E. P. (1982). China: Railways and Agricultural Development, 1875-1935 . Chicago: University of Chicago Geography Research Papers.

[31]. Lin, J. Y. (2015). One Belt and One Road" and Free Trade Zones-China's New Opening-up Initiatives. Frontiers of Economic in China, 10(4), 585-590.

[32]. Liu, H. (2015). A Comparative Study of Two Global Crises. Frontiers of Economics in China, 10(3), 396-413.

[33]. Martinson, R. D. (2014). Power to the Provinces: The Devolution of China's Maritime Rights Protection. China Brief, 14(17). 
[34]. mindanao.politics.com.ph. (2017, August 2). Mindanao Railway Project Might be 'Made in China'. Retrieved from mindanao.politics.com.ph/mindanao-railway-projectmight-made-china/

[35]. Mearsheimer, J. J. (2014, October 25). Can China Rise Peacefully? Retrieved May 16, 2018, from National Interest: https://nationalinterest.org/commentary/can-china-risepeacefully-10204

[36]. Mitchell, T., \& Yang, Y. (2016). China Rails Against Global 'Hype' on Overcapacity . Retrieved May 20, 2018, from https://www.ft.com/content/9ee9f1ca-2bca-11e6-a18da96ab29e3c95

[37]. Naughton, B. (2017). The Current Wave of State Enterprise Reform in China: A Preliminary Appraisal. Asian Economic Policy Review, 12(2), 282-298.

[38]. NDRC. (2015). Vision and Actions on Jointly Building Silk Road Economic Belt and 21st-Century Maritime Silk Road. Retrieved May 16, 2018, from http://en.ndrc.gov.cn/newsrelease/201503/t20150330_669367.html

[39]. New York Times. (2013). Speedy Trains Transform China. Retrieved May 21, 2018, from https://www.nytimes.com/2013/09/24/business/global/high-speed-train-system-ishuge-success-for-china.html?_r=0

[40]. Nikkei Asian Review. (2018). China Communications Construction Co. Ltd. Retrieved May 20, 2018, from https://asia.nikkei.com/Companies/China-CommunicationsConstruction-Co.-Ltd

[41]. Nikkei Asian Review. (2018, September 24). China Railway Group Ltd. Retrieved September 26, 2018, from https://asia.nikkei.com/Companies/China-Railway-GroupLtd

[42]. Norris, W. J. (2016). Chinese Economic Statecraft: Commercial Actors, Grand Strategy, and State Control. Ithaca: Cornell University Press.

[43]. Oi, J. C. (1 O'Trakoun, J. (2017). China's Belt and Road Initiative and Regional Perceptions of China. The Journal of the National Association for Business Economis, $52(3)$.

[44]. 995). The Role of the Local State in China's Transitional Economy. The China Quarterly, 144, 1132-1149.

[45]. Perkins, D. (2015). Understanding the Slowing Growth Rateof the People's Republic of China. Asian Development Review, 32(1), 1-30.

[46]. Peston, R. (2015). What is China's 'New Normal'? Retrieved May 20, 2018, from https://www.bbc.com/news/business-34344926

[47]. Ploberger, C. (2017). One Belt, One Road - China's New Grand Strategy. Journal of Chinese Economic and Business Studies, 15(3), 289-305.

[48]. Pomfret, R., \& Das, S. B. (2013). Subregional Zones and ASEAN Economic Community. In S. B. Das, J. Menon, R. Severino, \& O. L. Shrestha (Eds.), The ASEAN Economic Community: A Work in Progress (pp. 279-319). Singapore: ISEAS.

[49]. Qitao, L. (2018). Management's Address. Retrieved May 20, 2018, from http://en.ccccltd.cn/aboutcompany/managementsaddress/

[50]. Reilly, J. (2013). China and Japan in Myanmar: Aid, Natural Resources and Influence. Asian Studies Review, 37(2), 141-157.

[51]. Reuters. (2018). China Communications Construction Co Ltd (1800.HK). Retrieved May 20, 2018, from https://www.reuters.com/finance/stocks/companyofficers/1800.HK

[52]. Robins, F. (2013). The Uniqueness of Chinese Outward Foreign Direct Investment. Asian Business \& Management, 12(5), 525-537. 
[53]. Rolland, N. (2015). China's National Power: A Colossus with Iron or Clay Feet? In A. J. Tellis, A. Szalwinski, \& M. Wills (Eds.), Strategic Asia 2015-16: Foundations of National Power in the Asia-Pacific (pp. 23-54). NBR: Seattle.

[54]. Rolland, N. (2017). China's "Belt and Road Initiative": Underwhelming or GameChanger? The Washington Quarterly, 40(1), 127-142.

[55]. Smith, K. (2017). Will Alstom-Siemens Merger Check CRRC's International Expansion? . Retrieved May 21, 2018, from https://www.railjournal.com/opinion/willalstom-siemens-merger-check-crrcs-international-expansion/

[56]. Su, X. (2012). Rescaling the Chinese state and regionalization in the Great Mekong Subregion. Review of International Political Economy, 19(3), 501-527.

[57]. Sze, N., \& Wu, F. (2016). One Belt, One Road" The Internationalization of China's SOEs. Deloitte Perspective, 5, 5-21.

[58]. Tai, W.-P., \& Soong, J.-J. (2014). Trade Relations Between China and Southeast: Strategy and Challenge. The Chinese Economy, 47(3), 23-39.

[59]. Tsui, S., Wong, E., Chi, L. K., \& Tiejun, W. (2017). One Belt, One Road: China's Strategy for a New Global Financial Order. Monthly Review, 68(8).

[60]. The Economist. (2017, January 13). China Has Built the World's Largest Bullet-Train Network. Retrieved from https://www.economist.com/china/2017/01/13/china-hasbuilt-the-worlds-largest-bullet-train-network

[61]. Toops, S. (2016). Reflections on China's Belt and Road Initiative. Area Development and Policy, 1(3), 352-360.

[62]. Venzon, C. (2018). Duterte has three words on infrastructure: 'Build, Build, Build'. Retrieved May 3, 2018, from https://asia.nikkei.com/Spotlight/Asia-Insight/Dutertehas-three-words-on-infrastructure-Build-Build-Build

[63]. Wade, G. (2010, December 23). ASEAN Divides . Retrieved April 29, 2018, from http://www.newmandala.org/asean-divides/

[64]. Wang, L., Liu, Y., Mao, L., \& Sun, C. (2018). Potential Impacts of China 2030 HighSpeed Rail Network on Ground Transportation Accessibility. Sustainability, 10(4), 1 16.

[65]. WBG. (2016). Enhancing ASEAN Connectivity Monitoring and Evaluation. Washington DC: World Bank Group.

[66]. Weingast, B. R. (1995). The Economic Role of Political Institutions: MarketPreserving Federalism and Economic Development. Journal of Law, Economics, \& Organization, 11(1), 1-31.

[67]. Wu, H. X. (2014). Rethinking China's Industrialization: Economics Explanation of Roles of State and Government. Bijiao, 75(1), 1-23.

[68]. Xinhua. (2018, February 1). China's High-Speed Rail Tracks to Hit 38,000 KM by 2025. Retrieved from http://www.chinadaily.com.cn/a/201801/02/WS5a4b62cea31008cf16da4b27.html

[69]. Xu, C. (2011). The Fundamental Institutions of China's Reforms and Development. Journal of Economic Literature, 49(4), 1076-1151.

[70]. Yao, K., \& Meng, M. (2016). China Expects to Lay Off 1.8 million Workers in Coal, Steel Sectors. Retrieved May 19, 2018, from https://www.reuters.com/article/us-chinaeconomy-employment-idUSKCN0W205X

[71]. Yoshimatsu, H., \& Trinidad, D. D. (2010). Development Assistance, Strategic Interests, and the China Factor in Japan's Role in ASEAN Integration. Japanese Journal of Political Science, 11(2), 199-219. 
[72]. Yu, H. (2014). China's Eagerness to Export Its High-speed Rail Expertise to ASEAN Members. The Copenhagen Journal of Asian Studies, 32(2), 13-24.

[73]. Yu, H. (2017). China's Belt and Road Initiative and Its Implications for Southeast Asia. Asia Policy, 24, 117-122.

[74]. Yu, H., \& Yang, M. (2011). China Enters the Age of High-Speed Rail. In M. Yang, \& H. Yu, China's Industrial Development in the 21st Century (pp. 199-224). Singapore: World Scientific Publishing.

[75]. Yu, J. (2012). Firms with Chinese Characteristics: The Role of Companies in Chinese Foreign Policy . In N. Kitchen, China's Geoeconomic Strategy (pp. 32-37). London: LSE Ideas.

[76]. Zhang, J. (2010). Transformation of the Chinese enterprises. Singapore: Gale Asia.

[77]. Zhang, W., \& Alon, I. (2010). A Guide to the Top 100 Companies in China. Singapore: World Scientific Publishing.

[78]. Zuo, J., Chan, A. P., \& Zhao, Z.-Y. (2013). Supporting and Impeding Factors for Partnering in Construction - a China study. Facilities, 31(11), 468-488.

[79]. Zweig, D. (2002). Internationalizing China: Domestic Interests and Global Linkages. Ithaca: Cornel University Press. 